\title{
Correction to: Global Ramifications: Sovereignty and Autonomy
}

\section{Correction TO:}

Chapter 7 in: J. M. Domingues, Critical Theory and Political Modernity, https://doi.org/10.1007/978-3-030-02001-9_7

An error in the production process unfortunately led to publication of this chapter prematurely, before incorporation of the final corrections. The version supplied here has been corrected and approved by the author.

Note 3 has been updated in the chapter as below.

Emer de Vattel, Le droit des gens, ou Principes de la loi naturelle, appliqués à la conduite et aux affaires des Nations et des Souverains (London: Liberus Tutior, 1758), vol. 1, pp. 9, 18, 19, 6; vol. 2, pp. 1-2; Jens Battleson, A Genealogy of Sovereignty (Cambridge: Cambridge University Press, 1995); Gary Wilder, The French Imperial Nation-State: Negritude and Colonial Humanism between the World Wars (Chicago: The University of Chicago Press, 2005); Jean L. Cohen, Globalization and Sovereignty: Rethinking Legality, Legitimacy, and Constitutionalism (Cambridge: Cambridge University Press, 2012); Krishan Kumar, Visions of Empire: How Five Imperial Regimes Shaped the World (Princeton, NY: Princeton University Press, 2017).

The updated online version of the chapter can be found at https://doi.org/10.1007/978-3-030-02001-9_7

(C) The Author(s) 2019

J. M. Domingues, Critical Theory and Political Modernity, https://doi.org/10.1007/978-3-030-02001-9_10 